\title{
Estudio experimental de perfiles de temperatura en elementos de fábrica cerámica sometidos a altas temperaturas
}

\section{Experimental analysis of temperature profiles in ceramic brickwork elements subjected to high temperatures}

\author{
M. E. Maciá(*), A. Rolando(**)
}

Recepción/Received: 5-XI-12

Aceptación/Accepted: 19-VI-13

\section{RESUMEN}

En este artículo se analiza la transferencia de calor a través de un elemento de fábrica de ladrillo con el fin de conocer el comportamiento térmico de secciones de fábrica unidimensionales expuestas a altas temperaturas.

El objeto de los ensayos es construir curvas tiempo-temperatura en función de diversos escalones térmicos en régimen transitorio para determinar experimentalmente los perfiles de temperatura en el interior de un muro.

A través de este estudio es posible evidenciar el contenido de humedad absoluta de un elemento de fábrica a partir de los $300{ }^{\circ} \mathrm{C}$ (variación de las temperaturas en el interior del elemento), evitar el fenómeno asociado de la evaporación del agua durante el proceso térmico así como obtener perfiles de temperaturas que ayuden a calcular la sección eficaz de un elemento de fábrica sometido a altas temperaturas.

Palabras clave: fábrica de ladrillo; altas temperaturas; perfiles de temperatura; comportamiento termomecánico).

\section{ABSTRACT}

This article discusses heat transfer through a brick element in order to know the thermal behavior of onedimensional brickwork masonry samples exposed to high temperatures.

The object of the tests is to build time-temperature curves according to different thermal steps in transient to experimentally determine the temperature profiles in the interior of a wall.

Through this study, it is possible to demonstrate absolute moisture of a factory item from $300{ }^{\circ} \mathrm{C}$ (variation of temperatures in the interior of the element), avoid the associated phenomenon of evaporation of water during the thermal process as well as to obtain profiles of temperatures that help calculate the cross section of a factory element subjected to high temperatures.

Keywords: brickwork masonry; high temperatures; temperature profiles; thermo mechanical behavior.

\footnotetext{
(*) Universidad San Pablo CEU (Madrid, España).

(**) Universidad Politécnica de (Madrid, España).
} 


\section{INTRODUCCIÓN}

El objetivo de este trabajo consiste en obtener curvas experimentales de evolución de temperatura con el tiempo para muretes de fábrica expuestos a una ley no estacionaria de temperaturas. Se ha diseñado un dispositivo experimental para someter a las probetas a una evolución no estacionaria y uniforme de su campo de temperaturas. Se ha sometido a una de sus caras a un flujo de calor impuesto por una placa calentadora cerámica refractaria mientras que la otra cara se ha expuesto a la temperatura ambiente. Mediante un conjunto de termopares ubicados en el interior del murete se han obtenido diferentes curvas de temperatura en función del tiempo. Con objeto de analizar la transmisión de temperatura sobre los muretes a distintos escalones de temperatura y con objeto de validar el protocolo del ensayo y el dispositivo experimental, se han realizado un total de 48 ensayos.

Para asegurar que los resultados obtenidos en estos ensayos puedan ser aplicados con éxito, se deben alcanzar los siguientes objetivos:

1. Establecer un protocolo que permita asegurar la fiabilidad de los resultados.

2. Asegurar el carácter unidimensional de la transferencia de calor de los ensayos.

3. Diseñar el dispositivo experimental.

4. Validar los resultados del dispositivo experimental.

El carácter unidimensional del problema se ha asegurado a través de un diseño que no permita la transferencia de calor transversal. La validación del carácter unidimensional del problema se ha comprobado a través de la medida de diferentes temperaturas en un plano a una misma distancia de la cara expuesta al flujo de calor de la placa. También ha sido objeto de este trabajo la validación y la puesta a punto del dispositivo experimental.

\section{ESTADO DEL CONOCIMIENTO}

Aunque existen algunas recomendaciones y propuestas para la realización de ensayos de caracterización de ladrillos y morteros a temperatura ambiente no ocurre lo mismo cuando hay que evaluar la influencia de las altas temperaturas en esos materiales.

Los numerosos estudios de caracterización (1-8) que existen en la literatura relativos al estudio de elementos de fábrica a altas temperaturas se refieren, de manera general, a la variación de las propiedades de los materiales componentes de la fábrica en función de la temperatura de forma aislada y no del elemento formado por pieza-juntapieza. Por otra parte, los análisis por contrastación (9-13)

\section{INTRODUCTION}

The aim of this work is to obtain experimental timetemperature curves with time for brickwork masonry exposed to a non-stationary temperature law. An experimental device is designed to subject the samples to a non-stationary and uniform evolution of their field of temperature. One of its faces has been submitted to a heat flow imposed by a refractory ceramic heating plate while the other side has been exposed to room temperature. Through a set of thermocouples located inside the brickwork element, different curves of temperature in function of time have been obtained. In order to analyze the transmission of the temperature on the samples at different temperature steps and in order to validate the protocol of the trial and experimental device, there have been a total of 48 tests.

To ensure that the results obtained in these tests can be applied successful, it must achieve the following objectives:

1. Establish a protocol to ensure the reliability of the results.

2. Ensure the dimensional character of the heat transfer tests.

3. Design the experimental device.

4. Validate the results of the experimental device.

he one-dimensional nature of the problem has been secured through a design that does not allow transverse heat transfer. The validation of the one-dimensional character the problem has been proven through measurement of different temperatures in a plane at a same distance from the face exposed to the heat flow of plate. He has also been the subject of this paper the validation and tuning of the experimental device.

\section{STATE OF KNOWLEDGE}

Although there are some recommendations and proposals for the realization of characterization tests of bricks and mortar at room temperature it is not the case when it is necessary to evaluate the influence of the high temperatures in these materials.

The numerous studies of characterization (1-8) which exist in the literature relating to study of brickwork masonry elements to high temperatures refer, generally, solely to the variation of the properties of component materials of the brickwork masonry depending on the temperature and not to the element formed by piecejoint-piece. Moreover, the tests by contrast analyze (9-13) 
realizados a elementos de fábrica presentan gran disparidad de tamaños y formas que impiden la comparación de los resultados obtenidos.

Por ese motivo parece conveniente explicar el procedimiento de ensayo llevado a cabo en este estudio con el fin de proporcionar perfiles de temperatura en elementos de fábrica (tripletas) sometidos a altas temperaturas.

\section{PROGRAMA EXPERIMENTAL}

A continuación se explica, de forma pormenorizada, cual ha sido la elección del formato del elemento objeto de estudio, cómo se han realizado los muretes, cual ha sido el sistema de medición y control de la temperatura así como la instrumentación necesaria y la geometría y disposición del ensayo.

\subsection{Elección del formato y materiales}

Los datos obtenidos sobre el comportamiento de los muros de fábrica dependen, además de las condiciones ambientales (en este caso la temperatura), del formato de los muros y del material utilizado. Para elegir el tipo de probeta adecuado se basó en diversas recomendaciones (14-16), normativas (17-19) y estudios existentes (20-23).

Desde el principio se asumió que el tamaño del murete debía ser pequeño. Debía construirse sobre una superficie horizontal y su forma debía ser plana (24).

Con este formato se pretendía mejorar ciertas condiciones que se había comprobado, influían en la toma de medida:

- Se soslayaban los problemas de replanteo, que pueden existir en muros de gran tamaño.

- Se evitaba el efecto de arqueo del muro cuando la temperatura de las dos caras es diferente (esto es especialmente relevante cuando el muro es suficientemente grande y se encuentra sometido a altas temperaturas).

- Se eludía el efecto de la esbeltez, dado que no era objeto de estudio en este trabajo.

- Se garantizaba la planeidad y el paralelismo de las caras superior en inferior del murete para que el posterior reparto de la carga fuera homogéneo en la probeta.

Para la elaboración de los muretes-probeta se utilizaron ladrillos cerámicos métricos prensados, cara vista, comunes de la fábrica cerámica Malpesa, S.A. (sin tratamientos de hidrofugación y cocidos a temperaturas próximas a $900{ }^{\circ} \mathrm{C}$ ), cuyo formato era $240 \times 119 \mathrm{~mm}$ y un grueso de $5 \mathrm{~mm}$. Los ladrillos utilizados cumplen la normativa establecida. to brickwork masonry elements have large disparity of sizes and shapes that prevent the comparison of results obtained.

For this reason it seems appropriate to explain the test procedure carried out in this study in order to provide temperature profiles in brickwork masonry elements (triplets) subjected to high temperatures.

\section{EXPERIMENTAL PROGRAM}

The following explains, in detail, what has been the choice of the format of the element under study, how brickwork masonry walls has been made, which has been the measuring and temperature control system, as well as the choice of the necessary instrumentation and the geometry and arrangement of the test.

\subsection{Choice of format and materials}

Data obtained on the behavior of brickwork masonry walls depend, besides environmental conditions (in this case temperature), on format of the walls and the material used. To choose the appropriate specimen type is based on various existent recommendations (14-16), regulations (17-19) and studies (20-23).

From the beginning it was assumed that the size of brickwork masonry walls should be small. It must be built on a horizontal surface and its shape should be flat (24).

This format is intended to improve certain conditions that had been proved, influenced the decision of measure:

- Problems of laying out, which may exist in large size walls, were avoided.

- The effect of curvature of the wall when the temperature of its two sides is different (this is especially relevant when the wall is too large and subjected to high temperatures) was avoided.

- The effect of slenderness, since it was not studied in this work, was avoided.

- Flatness and parallelism of upper and lower faces of the wall for the homogeneity of load distribution in the specimen, was guaranteed.

For the preparation of the test-walls bricks, were used common ceramic metric bricks of Malpesa, S.A. (without hydrophobing treatments and cooked at temperatures near $900{ }^{\circ} \mathrm{C}$ ), which format was $240 \times 119 \mathrm{~mm}$ and a thickness of $50 \mathrm{~mm}$. Used bricks comply with the established standards. 
Se confecciona un mortero de albañilería Valsec $M-7,5$ de resistencia $7,5 \mathrm{~N} / \mathrm{mm}^{2}$. El mortero se amasó con una amasadora convencional de obra. El agua $(0,12$ litros/Kg) se incorporó a la masa progresivamente, hasta encontrar una manejabilidad adecuada. No se utilizaron aditivos, plastificantes o aireantes. La retención de agua del mortero se consideró correcta en su ejecución; el mortero no manifestó pérdidas bruscas de agua en su colocación y su trabajabilidad fue buena (24).

Para preparar convenientemente los muretes (absorber las irregularidades en la cara superior, garantizar buena adherencia entre la capa de refrentado y el murete, conseguir un acabado plano y con alta resistencia) se empleó escayola E-35 en la cara superior de las probetas. Este material tiene una alta resistencia mecánica y su puesta en obra es rápida y sencilla (el porcentaje de agua en masa con respecto a la escayola debe estar entre el 26$30 \%)$.

\subsection{Sistema de medición y control de temperatura}

Para la adopción de un sistema de medición se ha realizado una búsqueda bibliográfica y se ha intentado reproducir los sistemas de algunos autores (1-13) con el fin de optimizar la técnica. Se colocaron varios termopares en los muretes, practicando taladros a determinadas distancias y profundidades para obtener datos sobre la temperatura en el interior de los muretes (Figura 1).
A masonry mortar Valsec M-7.5 of $7.5 \mathrm{~N} / \mathrm{mm}^{2}$ strength is made. The mortar was mixed with a conventional construction site mixer. Water (0.12 liters $/ \mathrm{kg}$ ) was added to the mass gradually to reach an adequate workability. No additives, plasticizers or aerating were used. The mortar water retention was considered correct in their implementation, the mortar did not show sudden losses of water in its placement, and its workability was good (24).

To properly preparing the brickwork masonry walls (to absorb irregularities in the upper side, ensure good adhesion between the capping layer and the wall, get a flat finish and high resistance) plaster E-35 in the upper surface of the specimens was used. This material has a high strength and its use in construction is quick and easy (the percentage of water by mass with respect the plaster should be between 26-30\%).

\subsection{Measurement and control system of temperature}

For the adoption of a measurement system it has been performed a bibliographic search and it has been attempted to reproduce the systems of some authors (1-13) in order to optimize the technique. Several thermocouples were placed inside the walls, practicing drills at certain distances and depths to obtain data on the temperature inside the brickwork masonry walls (Figure 1).

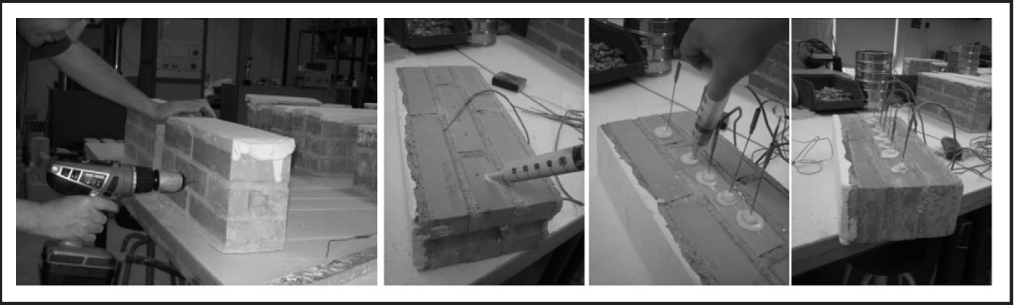

Figura 1. Preparación de los muretes para insertar termopares.

Figure 1. Preparation of the samples to insert thermocouples.

Con el fin de obtener datos fiables se procedió al relleno de escayola de los espacios intersticiales entre la fábrica y el termopar (debido a que se crea una pequeña cámara de aire que falsea los datos). El sistema de control de temperatura estaba centralizado en un adquisidor de datos que recibía la señal de los termopares que se situaron en el interior del murete y de un termopar adicional que recibía la señal de la placa calentadora que transfería la temperatura al elemento.

\subsection{Geometría y disposición del ensayo}

Dado que no existe un ensayo específico para la obtención de perfiles de temperatura se diseña un dispositivo para tal efecto (Figura 2). Los muretes se sitúan sobre
In order to obtain reliable data it was proceeded to plaster the interstitial spaces between the brickwork masonry walls and the thermocouples (because it creates a small air chamber that distorts the data). The temperature control system was centralized in a data acquisition system receiving the signal from the thermocouple that were placed inside the brickwork masonry walls and from an additional thermocouple receiving signal from the heater plate that transferred temperature to the element.

\subsection{Geometry and layout of the test}

Since there is no specific test for obtaining temperature profiles, a device is designed for that purpose (Figure 2). Brickwork masonry walls are placed on a horizontal surface, 
una superficie horizontal, se aíslan perimetralmente dejando una cara en contacto con la temperatura ambiente y se someten a la transmisión de calor por una cara mediante una placa calentadora cerámica refractaria. Las resistencias de calentamiento han sido fabricadas con una aleación de níquel-cromo. Tienen buenas prestaciones hasta $1.200{ }^{\circ} \mathrm{C}$ bajo condiciones cíclicas severas de calentamiento-enfriamiento. El carácter unidimensional del problema se ha asegurado a través de un diseño que no permita la transferencia de calor transversal. are perimetrally isolated leaving a face in contact with the room temperature and subjected to heat transmission on one side by a refractory ceramic hotplate. Heating resistors have been made from a nickel-chromium alloy. They have good performance up to $1200{ }^{\circ} \mathrm{C}$ under severe cyclic heating-cooling. The one-dimensional character of the problem has been secured through a design that does not allow transverse heat transfer.

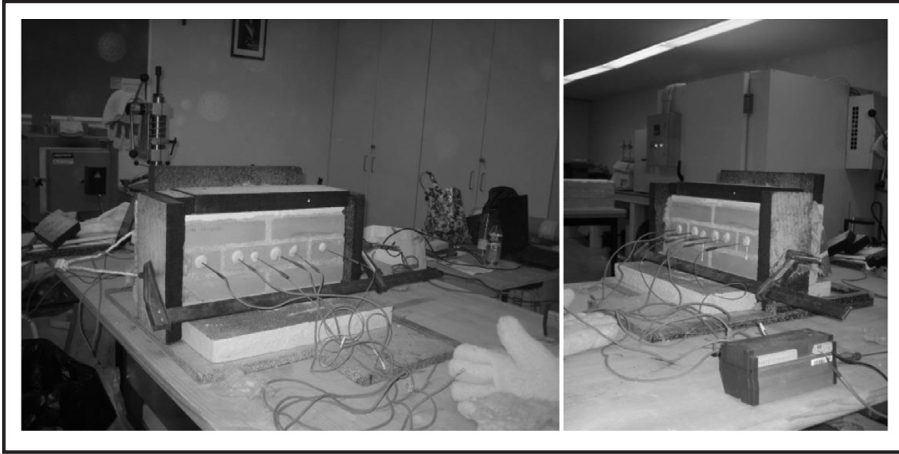

Figura 2. Preparación del sistema de adquisición de datos de temperatura. Figure 2. Preparation of the temperature data acquisition system.

Con el fin de aislar convenientemente el murete se dispone de una base de material aislante compuesto por fibras refractarias sobre el que se coloca la probeta. Las placas de fibras refractarias tienen una composición mineralógica formada por cordierita y mullita y alcanzan una temperatura de trabajo de $1.300^{\circ} \mathrm{C}$. Esta placa es la más adecuada para todo tipo de aplicaciones que estén sometidas a temperaturas superiores a los $1.000{ }^{\circ} \mathrm{C} y$ donde pueda haber llama directa o exposición a gases calientes. La temperatura máxima de utilización en continuo es de $1.260^{\circ} \mathrm{C}$. Esta placa es de gran versatilidad y permite su utilización donde se requiera un material rígido, autoportante y aislante que posea una buena resistencia a la erosión física (aislamiento de hornos en industria cerámica, barreras térmicas, aislamientos a altas temperaturas...). A continuación se rodea en los laterales, parte superior y una de las caras de material aislante (en este caso vidrio celular debido a la manejabilidad en el corte, tratamiento y sustitución de la pieza en caso de rotura por dilataciones debidas a la temperatura/por permitir un mejor manejo y adecuación del material aislante en los ensayos). De esta manera se asegura que el proceso térmico al que van a estar sometidas las probetas no sea un proceso adiabático puesto que el cajeado perimetral de las probetas debe minimizar las pérdidas laterales.

El perfil de temperaturas en los elementos se ha determinado mediante la colocación de 4 termopares situados en la parte central de la probeta (Figura 3) a distintas distancia de la cara no expuesta. Además de los termopares colocados en la parte central del murete a
In order to conveniently isolate the brickwork masonry walls it is set a base of insulating material comprising refractory fibers on which the specimen is placed. The refractory fiber plates have a mineralogical composition of cordierite and mullite and reach a temperature of $1300^{\circ} \mathrm{C}$. This plate is the best suited for all applications that are subject to temperatures above $1000{ }^{\circ} \mathrm{C}$ and where may exist flame or exposure to hot gases. The maximum temperature for continuous use is $1260{ }^{\circ} \mathrm{C}$. This plate is very versatile and can be used where it is required a rigid, self-supporting insulation material having a good physical erosion resistance (insulation of kilns in ceramic industry, thermal barriers thermal insulation at high temperatures...). Then is surrounded in the side, top and one side with an insulating material (in this case cellular glass due to the cut, treatment and replacement handling of the piece, if broken by expansion due to temperature, and to allow better management and fitting of insulation material in the trials). This way ensures that the thermal process that will be subjected specimens is not an adiabatic process since the peripheral recess of the specimens should minimize lateral losses.

The temperature profile in the elements was determined by a placing four thermocouples placed in the central part of the wall test (Figure 3) to different distance from the unexposed face. Besides thermocouples placed in the center of the brickwork masonry wall at distances 
$\mathrm{Tp} 1=7 \mathrm{~cm}, \mathrm{Tp} 2=5 \mathrm{~cm}, \mathrm{Tp} 3=3 \mathrm{~cm}$ y Tp4 $=1 \mathrm{~cm}$ se han dispuesto otros dos termopares de control cuyas denominaciones hacen referencia a los anteriores (a 5 y $3 \mathrm{~cm}$ ) de la cara no expuesta en ambos extremos para validar la unidimensionalidad del problema. También se ha utilizado un termopar adicional para medir la temperatura de la placa calentadora. El perfil térmico del elemento se ha obtenido para diferentes temperaturas de control de la placa, desde $50^{\circ} \mathrm{C}$ hasta $700{ }^{\circ} \mathrm{C}$.

Los ensayos para conocer los perfiles de temperatura en muretes de fábrica se realizaron en el Laboratorio de Materiales de la Escuela Politécnica Superior de la Universidad San Pablo CEU durante los meses de mayo y junio de 2009.

Después de colocar el murete según la disposición del ensayo se procede a calentar el murete por una cara durante al menos 210 minutos a distintos escalones de temperatura según las series que se indican a continuación. Durante el ensayo se mide la temperatura que se alcanza en el murete en diferentes puntos. El ensayo finaliza después de tres horas y media de calentamiento cuando el mayor perfil de temperatura se estabiliza.
$T p 1=7 \mathrm{~cm}, T p 2=5 \mathrm{~cm}, T p 3=3 \mathrm{~cm}$ and TP4 $=1 \mathrm{~cm}$ they are arranged two control thermocouples whose names do reference to the above ones (at 5 and $3 \mathrm{~cm}$ ) from the unexposed side at both ends to validate the dimensionality of the problem. It also is been used an additional thermocouple to measure the temperature of the heater plate. The thermal profile of the element has been obtained for different control temperatures of the plate, from $50^{\circ} \mathrm{C}$ to $700{ }^{\circ} \mathrm{C}$.

Tests for temperature profiles of were performed at the Laboratory of Materials of Higher Polytechnic School San Pablo CEU University during the months of May and June 2009.

After placing the brickwork masonry elements according to the layout of the test, is proceeded to heat the brickwork masonry elements on one side for at least 210 minutes at various steps of temperature according to the temperature series indicated below. During the test, It is measured the temperature reached in the brickwork masonry elements at different points. Test ends after three hours and a half of heating when the highest temperature profile stabilizes.

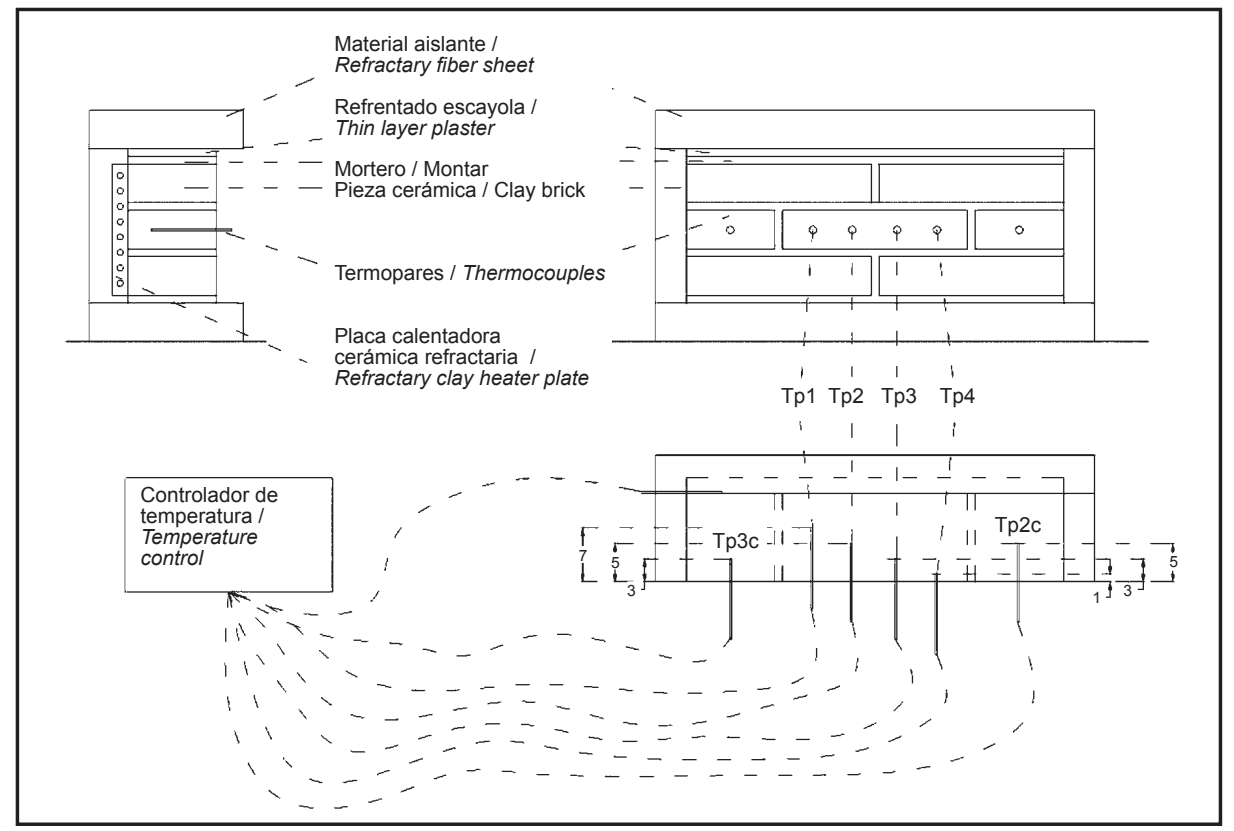

Figura 3. Geometría y disposición del ensayo.

Figure 3. Geometry and layout of the trial.

\subsection{Series de ensayo}

Se ensayan seis muretes por cada escalón de temperatura contemplado (desde $50{ }^{\circ} \mathrm{C}$ hasta $700{ }^{\circ} \mathrm{C}$ ) (Tabla 1 ).

\subsection{Test series}

Six brickwork masonry walls are tested for each contemplated temperature step (from $50{ }^{\circ} \mathrm{C}$ to $700{ }^{\circ} \mathrm{C}$ ) (Table 1). 
Tabla 1 / Table 1

Series de ensayo de las probetas.

Series of test specimens.

\begin{tabular}{|c|c|c|c|c|c|c|c|}
\hline $\begin{array}{c}\text { Código probeta / } \\
\text { Code test }\end{array}$ & $\begin{array}{l}\text { Temperatura/ } \\
\text { Temperature }\end{array}$ & $\begin{array}{c}\text { Código probeta/ } \\
\text { Code test }\end{array}$ & $\begin{array}{c}\text { Temperatura / } \\
\text { Temperature }\end{array}$ & $\begin{array}{l}\text { Código probeta / } \\
\text { Code test }\end{array}$ & $\begin{array}{c}\text { Temperatura / } \\
\text { Temperature }\end{array}$ & $\begin{array}{l}\text { Código probeta } \\
\text { / Code test }\end{array}$ & $\begin{array}{c}\text { Temperatura I } \\
\text { Temperature }\end{array}$ \\
\hline CR01 & \multirow{6}{*}{$50^{\circ} \mathrm{C}$} & CR13 & \multirow{6}{*}{$200^{\circ} \mathrm{C}$} & CR25 & \multirow{6}{*}{$400^{\circ} \mathrm{C}$} & CR37 & \multirow{6}{*}{$600^{\circ} \mathrm{C}$} \\
\hline CR02 & & CR14 & & CR26 & & CR38 & \\
\hline CR03 & & CR15 & & CR27 & & CR39 & \\
\hline CR04 & & CR16 & & CR28 & & CR40 & \\
\hline CR05 & & CR17 & & CR29 & & CR41 & \\
\hline CR06 & & CR18 & & CR30 & & CR42 & \\
\hline CR07 & \multirow{6}{*}{$100^{\circ} \mathrm{C}$} & CR19 & \multirow{6}{*}{$300^{\circ} \mathrm{C}$} & CR31 & \multirow{6}{*}{$500^{\circ} \mathrm{C}$} & CR43 & \multirow{6}{*}{$700^{\circ} \mathrm{C}$} \\
\hline CR08 & & CR20 & & CR32 & & CR44 & \\
\hline CR09 & & CR21 & & CR33 & & CR45 & \\
\hline CR10 & & CR22 & & CR34 & & CR46 & \\
\hline CR11 & & CR23 & & CR35 & & CR47 & \\
\hline CR12 & & CR24 & & CR36 & & CR48 & \\
\hline
\end{tabular}

\section{RESULTADOS}

Los resultados obtenidos de estos ensayos se refieren principalmente a la obtención de perfiles de temperatura según distintos escalones térmicos.

En todas ellas se reflejan dos tipos de curvas: la curva de temperatura del horno y las curvas obtenidas de la medición de los termopares situados a diferentes posiciones y profundidades en el interior del murete.

La curva de temperatura de la placa en los primeros escalones presenta sinuosidades cuando llega a la temperatura programada debido a que la placa calentadora contiene una resistencia eléctrica. Esto hace que tenga que regularse alcanzando temperaturas superiores en los primeros momentos para mantener la temperatura prefijada. A medida que la temperatura que se ha de alcanzar es más alta la regulación es menor.

Las curvas obtenidas a través de termopares en el interior del elemento permanecen constantes durante los primeros instantes del ensayo y aumentan progresivamente durante el transcurso del ensayo.

En las Figuras 4, 5 y 6 se muestran los diagramas típicos de transferencia de calor a través de un elemento sólido en los que apenas se observan variaciones reseñables durante el transcurso del ensayo.

A partir de calentar la probeta a $300^{\circ} \mathrm{C}$ se observa una meseta en la evolución de la temperatura con respecto al tiempo alrededor de los $100{ }^{\circ} \mathrm{C}$ (Figuras 7-11) para el termopar más profundo tp1 $(x=7 \mathrm{~cm})$. Después de realizar las series de ensayos correspondientes a los 8

\section{RESULTS}

The results of these tests are mainly concerned with obtaining temperature profiles under different thermal steps.

They all curves reflect two types: the oven temperature curve and the curves obtained by measuring thermocouples placed at different positions and depths within the brickwork masonry walls.

The temperature curve of the plate in the first steps presents sinuosity when it reaches the set temperature because the heating plate contains an electrical resistance. This means it has to be regulated reaching higher temperatures in the early stages to maintain preset temperature. The higher is the temperature to be attained the lower is the regulation.

The curves obtained via thermocouples inside the element remain constant during the first moments of the test and increase progressively during the course of the test.

In Figures 4, 5 and 6 are diagrams showing typical heat transfer through a solid element in which there are little variations to be worth to report just in the course of the trial.

After heating the specimen to $300^{\circ} \mathrm{C}$ it is shown a plateau in the evolution of temperature versus time at around $100^{\circ} \mathrm{C}$ (Figures 7-11) for the deeper thermocouple tp1 $(x=7 \mathrm{~cm})$. After performing the test series corresponding to the 8 studied temperature steps, they 
escalones de temperatura estudiados se dejan enfriar hasta temperatura ambiente en condiciones de laboratorio y posteriormente se realizan repeticiones en los tramos de temperatura desde $300{ }^{\circ} \mathrm{C}$ hasta $700{ }^{\circ} \mathrm{C}$ para poder evaluar este fenómeno. En la Figura 12 se observa cómo la meseta asociada a la evaporación del agua ha desaparecido.

Algunos autores $(13,25-27)$ aceptan como simplificación que se evapora toda la humedad del material a la temperatura de $100-115^{\circ} \mathrm{C}$ dando lugar a una discontinuidad en la curva de perfiles de temperatura. Se ha comprobado que esa simplificación da resultados aceptables para la mayoría de situaciones.

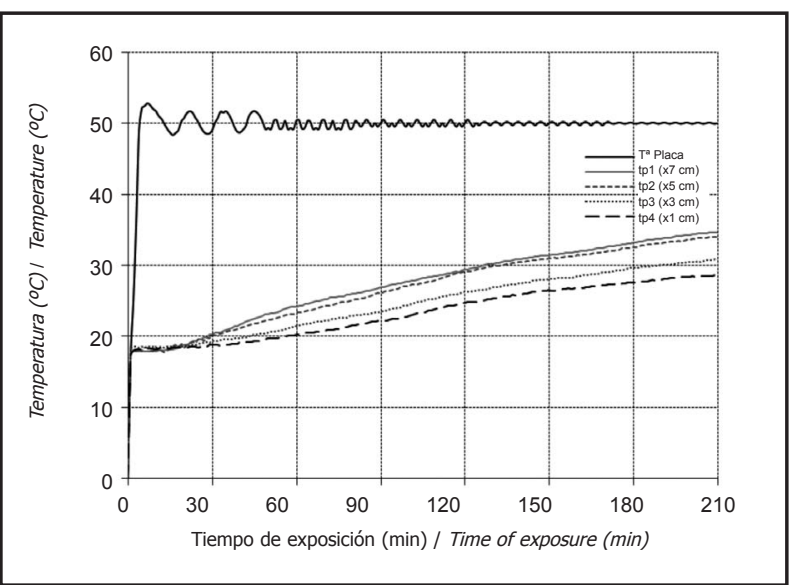

Figura 4. Curvas tiempo- temperatura medias de probetas sometidas a $50{ }^{\circ} \mathrm{C}$ (de CR01 a CR06 según Tabla 1). Figure 4. Time-temperature average curves of specimens subjected to $50{ }^{\circ} \mathrm{C}$ (CR01 to CR06 according to Table 1).

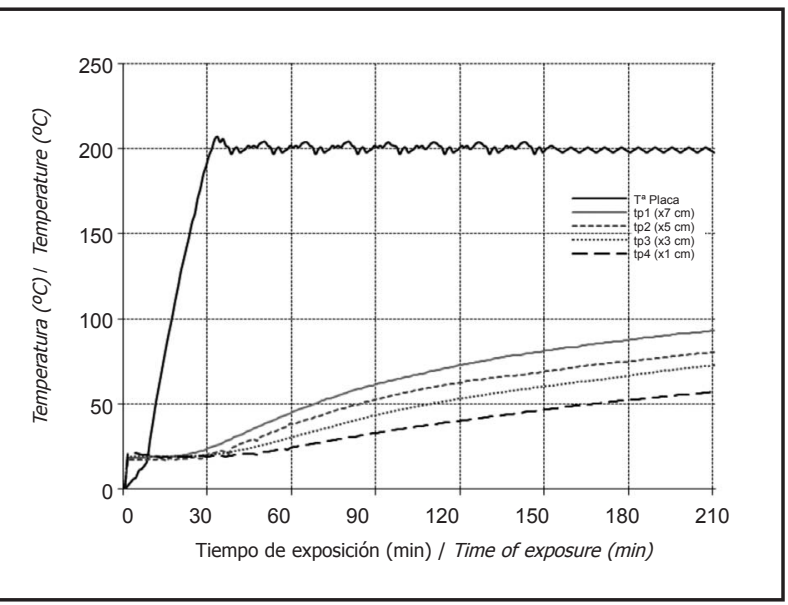

Figura 6. Curvas tiempo- temperatura medias de probetas sometidas a $200{ }^{\circ} \mathrm{C}$ (de CR13 a CR18 según Tabla 1). Figure 6. Time-temperature average curves of specimens subjected to $200{ }^{\circ} \mathrm{C}$ (CR13 to CR18 according to Table 1). are allowed to cool to ambient temperature in laboratory conditions and subsequently repetitions are performed in the temperature ranges from $300^{\circ} \mathrm{C}$ to $700^{\circ} \mathrm{C}$ to be able to evaluate this phenomenon Figure 12 shows how the plateau associated with the evaporation of the water is gone.

Some authors [13,25-27] accept as simplification that evaporates all moisture at temperature of $100-115^{\circ} \mathrm{C}$ resulting in a discontinuity in the curve of temperature profiles. It has been found that simplification gives acceptable results for most situations.

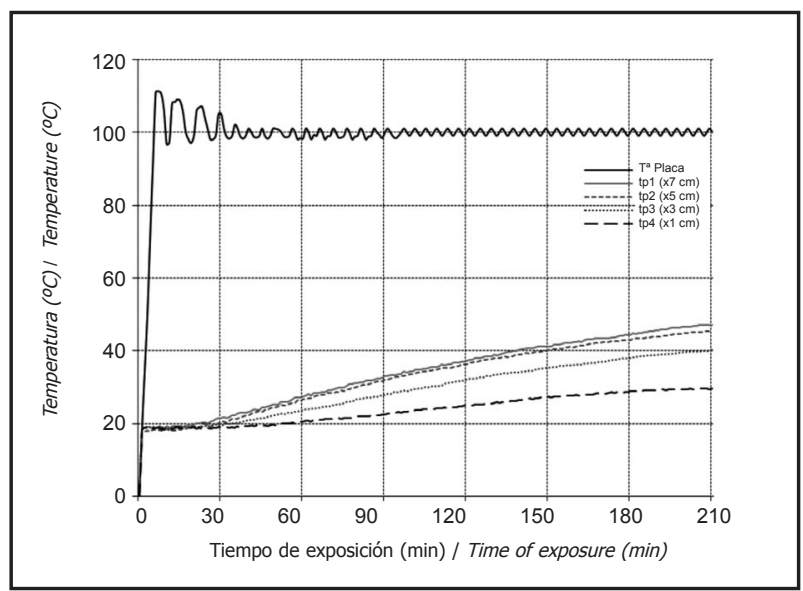

Figura 5. Curvas tiempo- temperatura medias de probetas sometidas a $100{ }^{\circ} \mathrm{C}$ (de CR07 a CR12 según Tabla 1). Figure 5. Time-temperature average curves of specimens subjected to $100{ }^{\circ} \mathrm{C}$ (CR07 to CR12 according to Table 1).

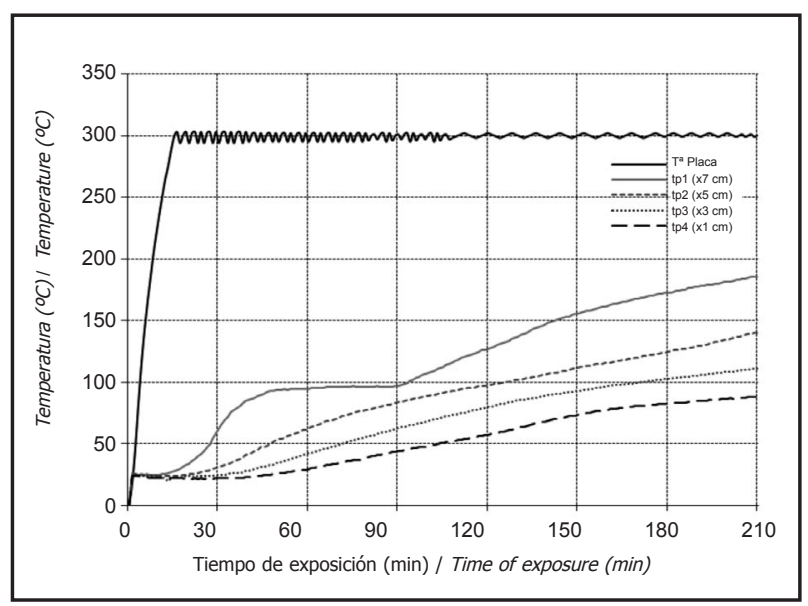

Figura 7. Curvas tiempo- temperatura medias de probetas sometidas a $300{ }^{\circ} \mathrm{C}$ (de CR19 a CR24 según Tabla 1).

Figure 7. Time-temperature average curves of specimens subjected to $300{ }^{\circ} \mathrm{C}$ (CR19 to CR24 according to Table 1). 


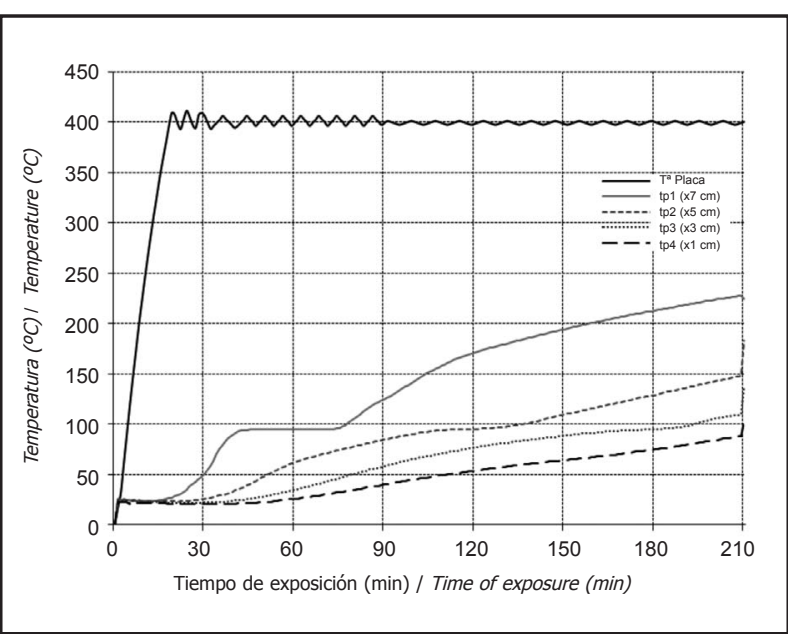

Figura 8. Curvas tiempo- temperatura medias de probetas sometidas a $400{ }^{\circ} \mathrm{C}$ (de CR25 a CR30 según Tabla 1). Figure 8. Time-temperature average curves of specimens subjected to $400{ }^{\circ} \mathrm{C}$ (CR25 to CR30 according to Table 1).

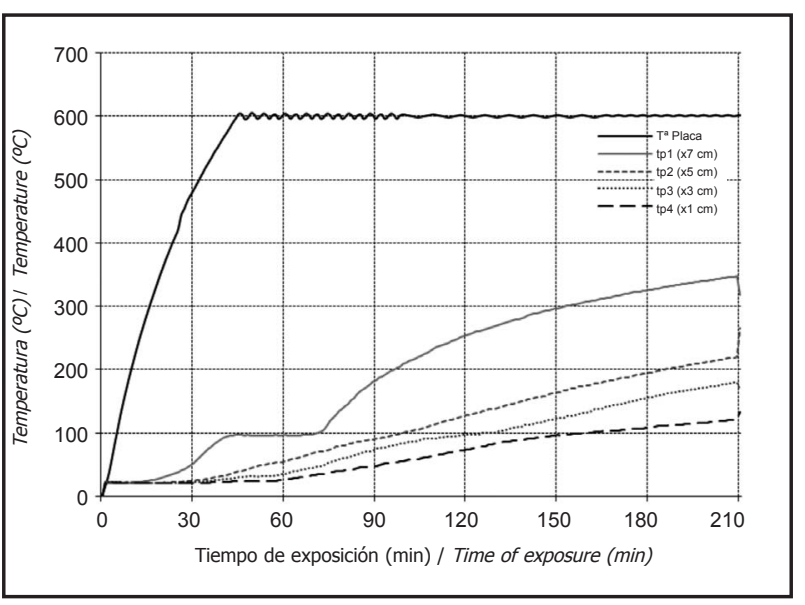

Figura 10. Curvas tiempo-temperatura medias de probetas sometidas a $600^{\circ} \mathrm{C}$ (de CR37 a CR42 según Tabla 1). Figure 10. Time-temperature average curves of specimens subjected to $600^{\circ} \mathrm{C}$ (CR37 to CR42 according to Table 1).

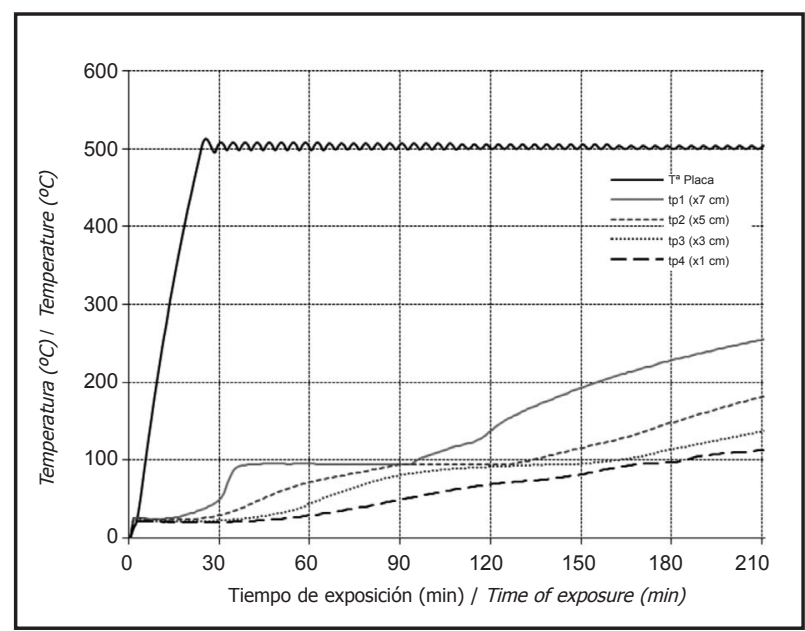

Figura 9. Curvas tiempo- temperatura medias de probetas sometidas a $500{ }^{\circ} \mathrm{C}$ (de CR31 a CR36 según Tabla 1). Figure 9. Time-temperature average curves of specimens subjected to $500^{\circ} \mathrm{C}$ (CR31 to CR36 according to Table 1).

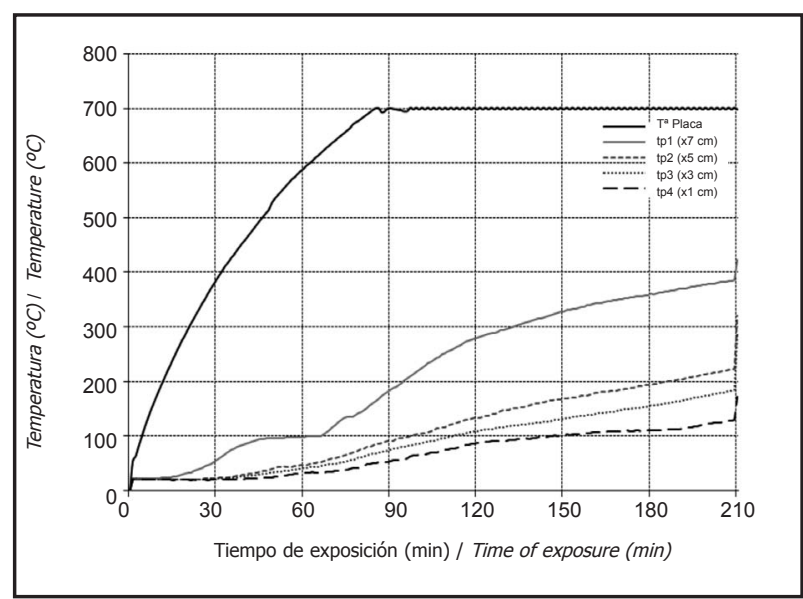

Figura 11. Curvas tiempo- temperatura medias de probetas sometidas a $700{ }^{\circ} \mathrm{C}$ (de CR43 a CR48 según Tabla 1).

Figure 11. Time-temperature average curves of specimens subjected to $700{ }^{\circ} \mathrm{C}$ (CR43 to CR48 according to Table 1).

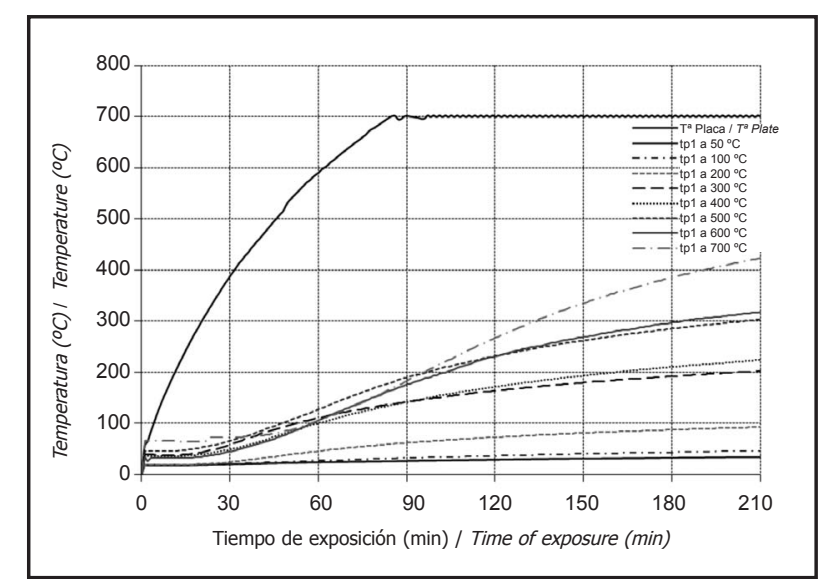

Figura 12. Curvas tiempo-temperatura medias del termopar 1

$(x=7 \mathrm{~cm})$ según rango de temperaturas $50^{\circ} \mathrm{C}-700^{\circ} \mathrm{C}$.

Figure 12. Time-temperature average curves stockings

thermocouple $1(x=7 \mathrm{~cm})$ according to range of temperatures $50^{\circ} \mathrm{C}-700^{\circ} \mathrm{C}$. 
Cuando se aplica una determinada temperatura se produce una resistencia del mortero a la transmisión del calor. Cuando se alcanzan temperaturas de $100{ }^{\circ} \mathrm{C}$ y mientras exista agua evaporable en los poros la temperatura permanece constante, indicada por una zona plana en las figuras, aunque aumente la temperatura en la superficie. Al desaparecer la fase líquida de los poros la transmisión de calor, viene indicada por un aumento de la temperatura en el material, se hace progresivamente lineal. En estos niveles de temperatura las fases sólidas son las responsables de la transmisión del calor, y también el aire caliente o vapor que debe quedar encerrado en los mismos. Existe a lo largo del ensayo un gradiente de temperatura en el interior del mortero.

Aunque el foco de calor cese, la temperatura en el interior de los morteros sigue aumentando debido al gradiente térmico creado en su interior. Sin embargo no se llegan a alcanzar las temperaturas de la superficie del mortero.

Los gradientes térmicos que determinan la capacidad de transmisión de calor en el mortero M-7,5 señalan también la aparición de una meseta a $100{ }^{\circ} \mathrm{C}$, más perceptible en las zonas interiores del mortero, propia de los procesos de transformación del agua líquida en vapor. No se detectaron daños por explosión de acumulación de presiones de vapor en el interior en ninguno de los ensayos realizados, por lo que se supone que su capacidad para liberar el vapor es buena.

Después de repetir el ensayo las temperaturas máximas alcanzadas a los 210 minutos de ensayo son un $15-20 \%$ superiores a las alcanzadas en el primer ensayo.

La diferencia de temperaturas en todos los termopares situados a la misma distancia en cada serie de 6 ensayos no sobrepasa el 7,5\% de la temperatura media. Así, el error asociado a suponer el problema unidimensional, es aceptable.

Existen algunos ensayos realizados sobre el comportamiento de las estructuras de fábrica en caso de incendio en función del contenido de humedad en el mortero (28) durante los primeros $150{ }^{\circ} \mathrm{C}$ de exposición al fuego. En esos estudios se aprecia la existencia de una meseta de evaporación de la humedad que se analizó incluso variando el tipo de unidades de fábrica empleadas en la elaboración de los muretes. Se puede decir que los termopares que más acusaron este fenómeno fueron los situados en las caras más cercanas al foco del calor mientras que los termopares más alejados señalan que la pérdida de humedad se realiza de forma creciente y progresiva.

También existen otros estudios (29) en los que se realizan comparaciones entre ensayos y simulaciones por ordenador. En algunos de los casos (generalmente en las mediciones realizadas por los termopares más cercanos
When applying a certain temperature a resistance of the mortar to heat transmission occurs. When temperatures reached $100{ }^{\circ} \mathrm{C}$ and while there is evaporable water in the pores, the temperature remains constant, indicated by a flat area in the figures, although the temperature rises at the surface. When the liquid phase of the pores disappears, the heat transfer indicated by a temperature increase in the material, it is made progressively linear. At these temperature levels solid phases are responsible for transmission of heat, and also for the hot air or steam that must be enclosed in them exists along the test a gradient temperature inside the mortar.

While the focus of heat ceases, the temperature inside the mortars follows increasing due to the thermal gradient created within. However ever reach the surface temperatures of the mortar.

Thermal gradients which determine the heat transfer capacity in the mortar M-7, 5 also indicate the appearance of a plateau at $100{ }^{\circ} \mathrm{C}$, more perceptible in the interior areas of mortar, typical of processes of transformation of liquid water into steam. No damage was detected by explosion of vapor pressure buildup inside in any test performed, so it is assumed that their capacity to release steam is good.

After repeating the test the maximum temperatures reached at 210 minutes of the test are $15-20 \%$ higher than those achieved in the first test.

The temperature difference at all thermocouples placed at the same distance in each series of 6 tests does not exceed $7.5 \%$ in average temperature. Thus, the error associated with assuming the one-dimensional problem, is acceptable.

There are some tests conducted on the behavior of brick wall masonry structures on fire depending on the moisture content in the mortar (28) during the first $150{ }^{\circ} \mathrm{C}$ fire exposure. In these studies can be seen the existence of a plateau moisture evaporation that was analyzed even varying the type of brickwork masonry units used in the preparation of walls. It could be said that thermocouples that most accused this phenomenon were those located on the faces closest to the heat source while the thermocouples farthest of this, point that the loss of moisture is done in a growing progressive way.

There are other studies (29) in which comparisons are made between tests and computer simulations. In some cases (usually measurements made by thermocouples closest to the heat source) the water evaporation occurs 
al foco de calor) la evaporación del agua se produce de forma más acusada en el ensayo y es ligeramente inferior en la previsión mediante simulación. Cabe señalar que en estos ensayos cuando este fenómeno se produce lo hace a temperaturas inferiores a los $50{ }^{\circ} \mathrm{C}$ y durante 30 minutos aproximadamente lo que indica que la tipología, el material empleado o la cantidad de humedad en la fábrica no son similares a las empleadas en el sistema expuesto en este trabajo.

A partir de la obtención experimental de las curvas tiempo-temperatura es posible determinar los perfiles de temperatura para cada uno de los escalones térmicos estudiados.

\section{Perfiles de temperatura}

La correcta determinación del perfil de temperaturas en el murete de fábrica es un factor clave para obtener un resultado adecuado en la medida de las tensiones y deformaciones en la probeta.

Aunque hay varios estudios $(30,31)$, que definen los perfiles de temperaturas debido a la heterogeneidad de las estructuras de fábrica no es posible realizar una comparativa directa entre ellos si bien las similitudes son evidentes.

En las siguientes gráficas (Figuras 13 a 20) se presentan los perfiles de temperatura de los muretes sometidos a los distintos escalones térmicos. Estos perfiles han sido obtenidos a partir de los resultados de las curvas tiempotemperatura (Figuras 4 a 11).

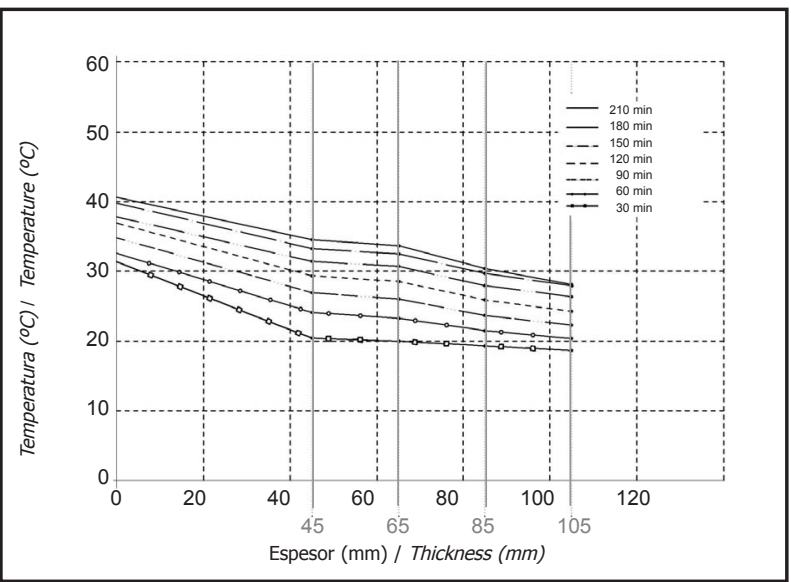

Figura 13. Perfiles de temperatura medios en las probetas (de CR01 a CR06 según Tabla 1) a $50{ }^{\circ} \mathrm{C}$.

Figure 13. Average temperature profiles (CR01 to CR06 according to Table 1) specimens at $50^{\circ} \mathrm{C}$. more markedly in the trial and is slightly lower in the forecast by simulation. Note that in these tests when this phenomenon occurs it does so at temperatures below $50{ }^{\circ} \mathrm{C}$ and for approximately 30 minutes, indicating that the typology, material used or the amount of moisture in the brickwork masonry wall are not similar to those used in the system presented in this work.

From experimental obtaining time-temperature curves it is possible to determine the temperature profiles for each of the thermal steps studied.

\section{Temperature profiles}

The correct determination of the temperature profile in the brickwork masonry wall is a key to obtain an adequate result in the measurement of stresses and strains in the specimen.

Although there are several studies $(30,31)$, which defines the temperature profiles due to the heterogeneity of masonry structures is not possible to make a direct comparison between them although the similarities are apparent.

In the graphs below (Figs. 13 to 20) are represented the temperature profiles of the walls subjected to different thermal steps. These profiles have been obtained from the results of the time-temperature curves (Figs. 4 to 11).

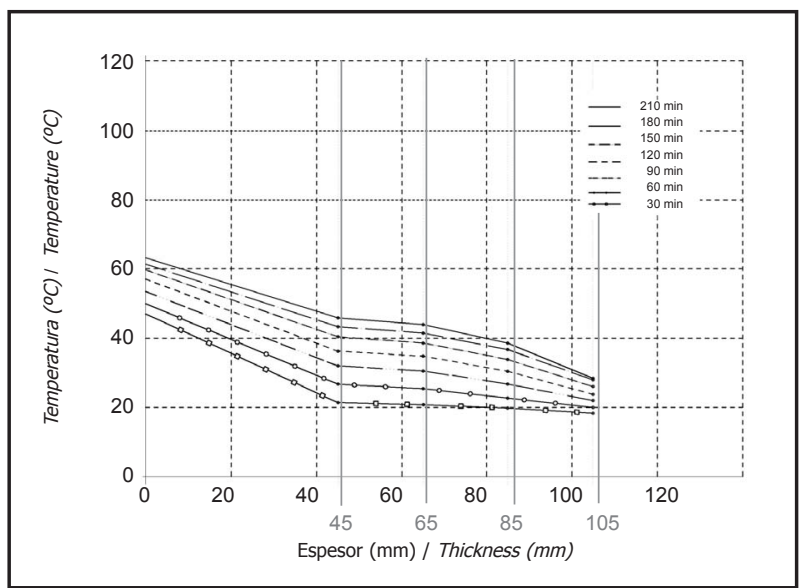

Figura 14. Perfiles de temperatura medios en las probetas (de CR07 a CR12 según Tabla 1) a $100{ }^{\circ} \mathrm{C}$.

Figure 14. Average temperature profiles (CR07 to CR12 according to Table 1) specimens at $100^{\circ} \mathrm{C}$. 


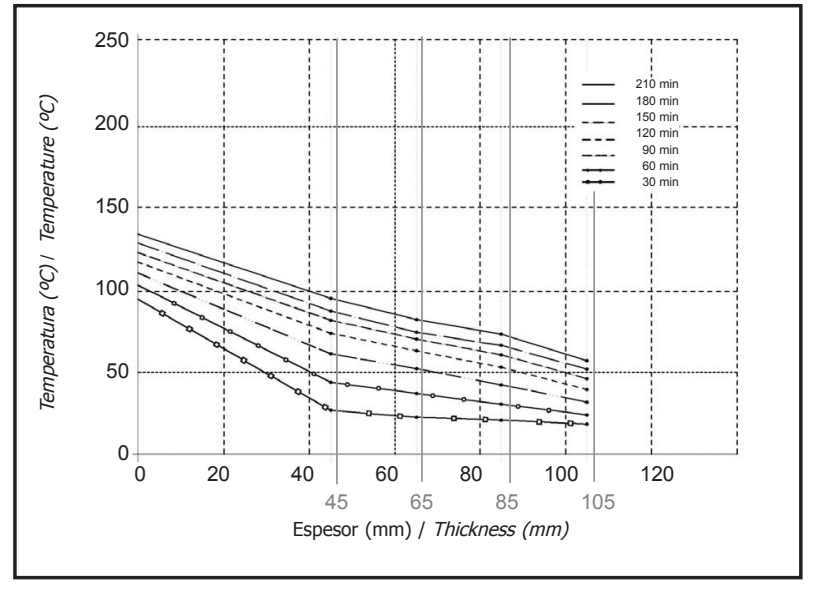

Figura 15. Perfiles de temperatura medios en las probetas (de CR13 a CR18 según Tabla 1) a $200^{\circ} \mathrm{C}$.

Figure 15. Average temperature profiles (CR13 to CR18 according to Table 1) specimens at $200^{\circ} \mathrm{C}$.

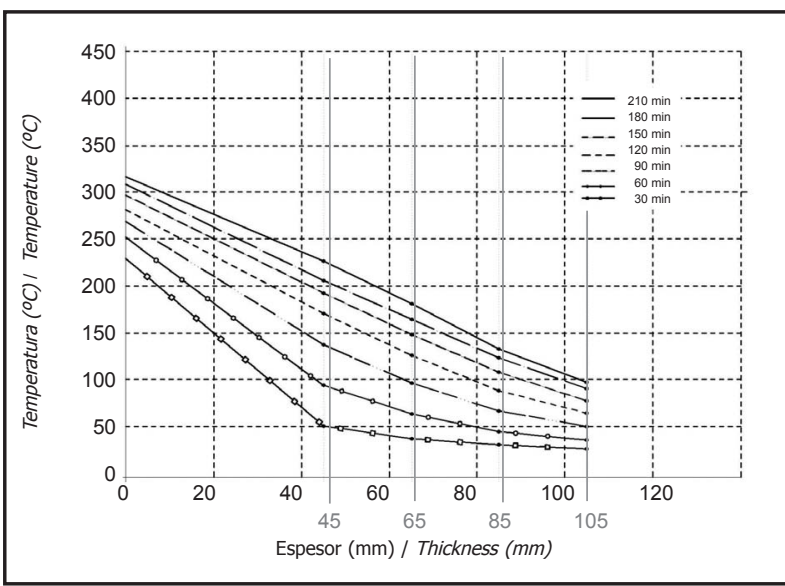

Figura 17. Perfiles de temperatura medios en las probetas (de CR25 a CR30 según Tabla 1) a $400{ }^{\circ} \mathrm{C}$

Figure 17. Average temperature profiles (CR25 to CR30 according to Table 1) specimens at $400^{\circ} \mathrm{C}$.

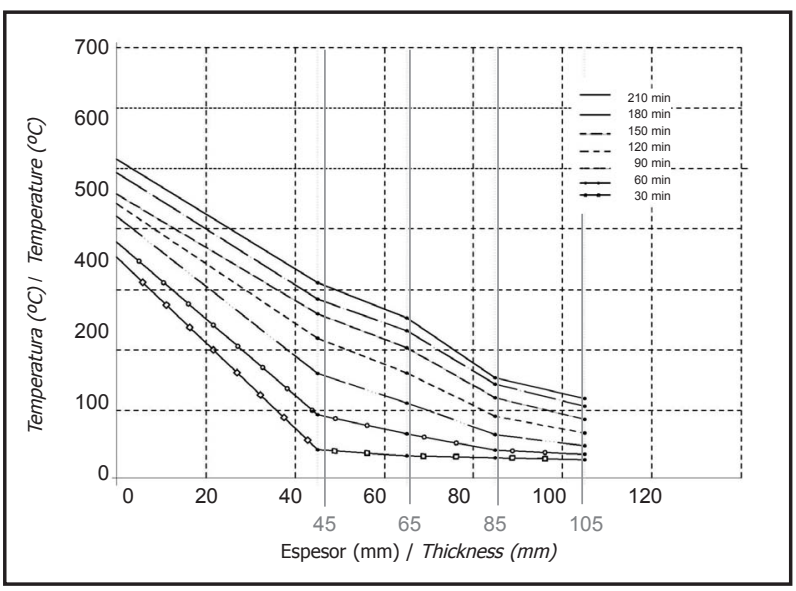

Figura 19. Perfiles de temperatura medios en las probetas (de CR37 a CR42 según Tabla 1) a $600{ }^{\circ} \mathrm{C}$.

Figure 19. Average temperature profiles (CR37 to CR42 according to Table 1) specimens at $600^{\circ} \mathrm{C}$.

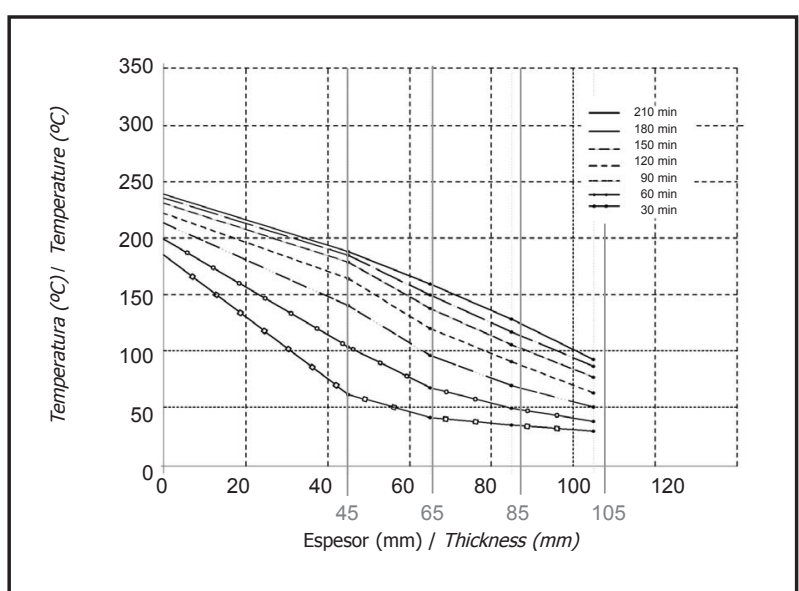

Figura 16. Perfiles de temperatura medios en las probetas (de CR19 a CR24 según Tabla 1) a $300^{\circ} \mathrm{C}$.

Figure 16. Average temperature profiles (CR19 to CR24 according to Table 1) specimens at $300^{\circ} \mathrm{C}$.

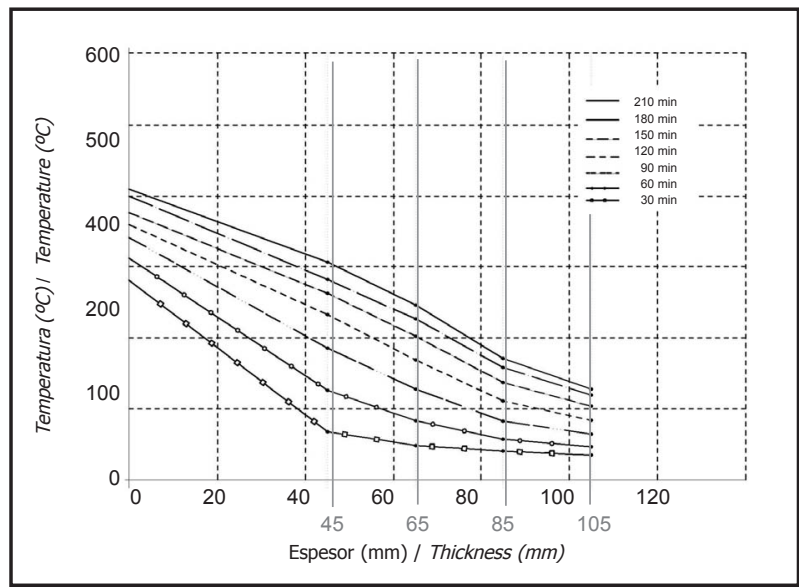

Figura 18. Perfiles de temperatura medios en las probetas (de CR31 a CR36 según Tabla 1) a $500^{\circ} \mathrm{C}$.

Figure 18. Average temperature profiles (CR31 to CR36 according to Table 1) specimens at $500^{\circ} \mathrm{C}$.

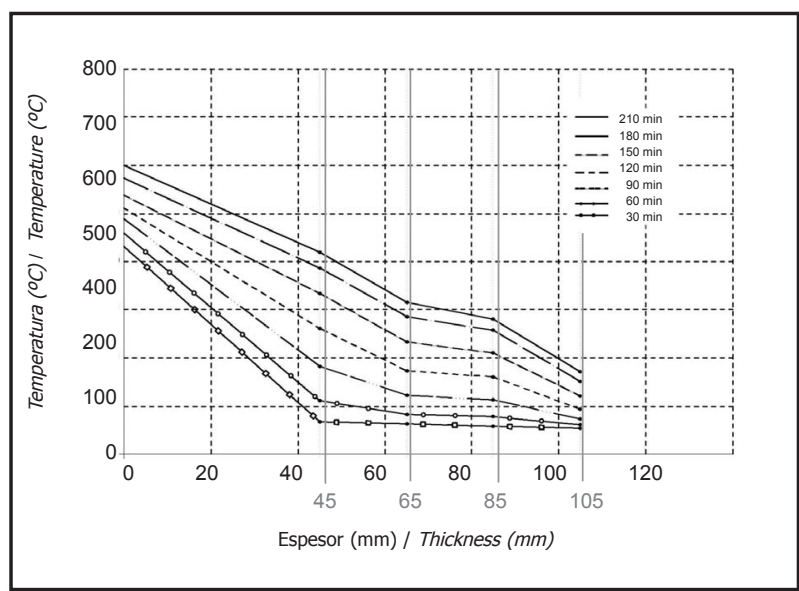

Figura 20. Perfiles de temperatura medios en las probetas (de CR43 a CR48 según Tabla 1) a $700{ }^{\circ} \mathrm{C}$.

Figure 20. Average temperature profiles (CR43 to CR48 according to Table 1) specimens at $700^{\circ} \mathrm{C}$. 


\section{DISCUSIÓN}

A partir de los resultados experimentales obtenidos en este estudio es posible extraer las siguientes conclusiones:

- El contenido de humedad absoluta de las probetas cerámicas se evidencia a través de una meseta en las curvas tiempo-temperatura a partir del calentamiento de la probeta superior a los $300^{\circ} \mathrm{C}$ en el momento en el que se alcanzan los $100{ }^{\circ} \mathrm{C}$. A esta temperatura el calor se invierte en evaporar el agua del interior (relación con la humedad natural de la probeta) realizando un cambio de fase a temperatura constante.

- Una misma probeta sometida a dos ensayos en días consecutivos muestra un resultado cualitativamente diferente. En el segundo día no aparece la meseta asociada a la evaporación del agua. Se considera que la evaporación del agua (debida a la humedad natural de la fábrica y el mortero) se realiza en el primer ensayo puesto que en el segundo ensayo no se obtiene esa meseta. Se constata que el tiempo que ha transcurrido entre un ensayo y la repetición (1 día) no es suficiente para rehidratar la probeta. La razón de encontrar una meseta asociada a la temperatura en un ensayo repetido con un mes de diferencia en una pieza cerámica puede ser debido a la gresificación del material (herencia que se encuentra el siguiente ensayo debida a la exposición prolongada a altas temperaturas) y por tanto con la consiguiente disminución de la porosidad el mismo.

- El hecho de calentar la probeta una vez antes de obtener los perfiles reales de temperatura puede servir como preparación para los ensayos en los que se quiera evitar el fenómeno de la evaporación de agua del elemento puesto que desaparecerá la meseta que está asociada a esta situación.

- Debido al contenido de humedad de las probetas cerámicas la repetición de un ensayo sobre una probeta ya ensayada puede originar diferencias significativas en la temperatura de los termopares (en algunos casos entre un 20 y un $30 \%$ ).

\section{DISCUSSION}

From the experimental results obtained in this study can be extracted the following conclusions:

- The absolute moisture content of the ceramic specimens is evidenced by a plateau on the temperature-time curves from the heating of the wall above $300{ }^{\circ} \mathrm{C}$ at the time the $100{ }^{\circ} \mathrm{C}$ are reached. To this temperature the heat is employed to evaporate the water inside (relation with the natural moisture of the specimen) by performing a phase change at constant temperature.

- A single specimen under two tests on consecutive days shows a qualitatively different result. On the second day the plateau associated with the evaporation of water does not appear. It is considered that the evaporation of water (due to the natural moisture of the brickwork masonry and the mortar) is performed in the first test since in the second trial that plateau is not obtained. It is found that the time elapsed between a test and the repetition (1 day) is insufficient to rehydrate the specimen. The reason for finding a temperature associated plateau in a trial repeated in a lapse of one month in a ceramic piece can be due to the vitrification of the material (inheritance that is found in the following test due to prolonged exposure to high temperatures) and therefore with the consequently porosity decline in it.

- The fact of heating the specimen once before getting the actual temperature profiles can serve as a preparation for the tests in which they want avoid the phenomenon of evaporation of water of the element because the plateau that is associated with this situation will disappear.

- Due to the moisture content of the samples, the repetition of a test on a specimen already tested may cause significant differences in temperature of thermocouples (in some cases between 20 and 30\%).

\section{BIBLIOGRAFÍA / BIBLIOGRAPHY}

(1) Lie, T.T.: Fire and Building, Applied Science Publishers. Ltd., London, 276 pp. (1972).

(2) Malhotra, H.L.: Properties of materials. Design of fire-resisting structures. Surrey University Press. I.S.B.N: 0-903384-28-0, pp.: 48-53, 75-81 (1982).

(3) Harmathy, T.: Properties of building materials: Bases for fire safety design. ISSN: 1-85166-012-7. Design of structures against fire. Proceedings of the International Conference on Design of structures against fire, held at Aston University, Birmingham. 15 and 16 April 1986, pp.: 87-104 (1986).

(4) Schneider U.: Modelling of concrete behaviour at high temperatures. ISSN: 1-85166-012-7. Design of structures against fire. Proceedings of the International Conference on Design of structures against fire, held at Aston University, Birmingham. 15 and 16 April 1986, pp.: 53-69 (1986).

(5) Gawin, D.; Majorana, C.E.; Schrefler, B.A.: Numerical analysis of hygro-thermal behaviour and damage of concrete at high temperature. Mechanics of cohesive-frictional materials. n. 4, pp.: $37-74$ (1999). 
(6) Cerny, R.; wood, J.; J. Podebradska, J.; et to the: The effect of compressive stress on thermal and hygric properties of Portland cement mortar in wide temperature and moisture ranges. Cem. Concr. Res. 30, pp.: 1267-1276 (2000).

(7) Boussa, H.; Mounajed, G.; Menou, A.; Grondin, J.: Micro structural origin of the app.arent thermal transient creep of concrete at high temperature. Internal Report. CSTB. France (2003).

(8) Cerny, R.: Properties of cementitious composites at high temperatures. Thermophysics 2008. Kocovce, pp.: 15-25 (2008).

(9) Lawrence, S.J.; Gnanakrishnan, N.: The Fire Resistance of Masonry Walls. An Overview. First National Structural Engineering Conference. Melbourne, 26-28 August (1987).

(10) Gnanakrishnan, N.; Lawther, R.: Some aspects of the fire performance of single leaf masonry construction. International symposium on fire for building structures and safety engineering, Melbourne. The Institution of Engineers Australia. National Conference Publication No. 89/16, pp.: 93-99 (1989).

(11) Hu X.F.; Lie, T.T., Polomark, G.M.; MacLaurin, J.W.: Thermal properties of building materials at elevated temperatures. National Research Council Canada. Internal report (1993) №.643.

(12) Hahn, C.: Experience of Fire Behaviour of Masonry. 10th International Brick and block Masonry Conference. Bowdin Coll, Calgary, Canada, Jul 05-07, 1994, pp.: 1089-1092 (1994).

(13) Nguyen,T.; Chammas, R.; Meftah, F.; Mebarki, A.: The behaviour of masonry walls subjected to fire: Modelling and parametrical studies in the case of hollow burnt-clay bricks. Fire Safety Journal No. 44, pp.: 629-641 (2009).

(14) K. Wesche, K.; Ilantzis, A.: General recommendations for methods of testing load bearing walls. Materials and Structures, RILEM, pp.: 433-445 (1980).

(15) Mann, W.; ATS, M.: Investigations on the effect of different forms of test samples to test the compressive strength of masonry. Proc. 10th Int. Brick and Block Masonry Conf. Calgary, Alberta, pp.: 1305-1313 (1994).

(16) Piet 70: factory works. Requirements of the Eduardo Torroja Institute. Madrid (1971).

(17) ASTM C1314 - 11a: Standard Test Method for Compressive Strength of Masonry Prisms. American Society for Testing and Materials. ASTM International. Dec. (2011).

(18) CRD-C 643-01: Standard Test Methods for Compressive Strength of Masonry Prisms. http://www.wes.army.mil/SL/MTC/handbook/ CRD_C643.pdf

(19) UNE EN 1996-1-2:2005. Project of factory structures. Part 1-2: General rules. Structural design in case of fire. AENOR.

(20) Khalaf, F. M.; Hendry, A. W.; Fairbairn, D.R.: Study of the compressive strength of blockwork masonry ACI Structural Journal.., pp.: 367-375 (1990).

(21) Purkiss, J.A.: Fire safety engineering. Design of structures. Ed. Butterworth Heinemann. I.S. B:n: 0-7506-0609-6 (1996).

(22) Vermeltfoort, A.: Brick-mortar interaction in masonry under compression. Eindhoven University of Technology. The Netherlands. ISBN: 90-68-14-582-7 (2005).

(23) García, D.: Experimental and numerical analysis of stone masonry walls strengthened with advanced composite materials. Doctoral Thesis. University of the Basque country, pp.: 247 (2009).

(24) Macia, M.E.; Rolando, A.: Young Modulus variation of a brickwork masonry element submitted to high temperatures. Mater. Construcc., vol. 63, no 309, pp.:105-116. ISSN: 0465-2746 (2012).

(25) Grant, C.; Pagni, P.J.: Thermal and mechanical behaviour of building structures at fire exposure. Fire safety science: Proceedings of the first international symposium. ISBN: 0-89116-456-1, pp.: 237-247 (1986).

(26) Cooke, G.M.E.; Virdi K.S.; Jeyarupalingam, N.: (1996): The thermal böwing of brick walls exposed to fire on one side. Proceedings of the Interflam '96 International Conference. Cambridge. Published by Inerscience communications. Ltd, London, pp.: 915-919.

(27) Nadjai, A.: Behaviour of masonry walls in fire situations compartment. Third International Workshop Structures in Fire. Ottawa, May 2004. S3-1 paper, pp.: 99-117 (2004).

(28) Welch, S.: Developing a model for thermal performance of masonry exposed to fire. First International Workshop Structures in fire. Copenhagen-June (2000).

(29) Harmathy, T.: Properties of building materials: Bases for fire safety design. ISSN: 1-85166-012-7. Design of structures against fire. Proceedings of the International Conference on Design of structures against fire, held at Aston University, Birmingham, pp.: 87-104 (1986).

(30) Nadjai, A.; O'Garra, M.; Ali, F.A.; Laverty, D. A numerical model for the behaviour of the masonry under elevated temperatures. Fire and Materials, 27 (DOI: 10.1002/fam.824), pp.: 163-182 (2003).

(31) Gnanakrishnan, N.; Lawther, R.: Some aspects of the fire performance of single leaf masonry construction. International symposium on fire for building structures and safety engineering, Melbourne. The Institution of Engineers Australia. National Conference Publication No. 89/16, pp.: 93-99 (1989). 